\title{
Quality, Satisfaction and Industrial Disputes in the Tourist Accommodation Services of the State of Mérida, Venezuela
}

\author{
Flora M. Díaz-Pérez, Maria Bethencourt-Cejas, Marysela C. Morillo-Moreno \\ University of La Laguna, La Laguna, Spain \\ Email: fdiazp@ull.es, mbethen@ull.es, morillom@ula.ve
}

Received January 3, 2013; revised February 5, 2013; accepted February 12, 2013

Copyright (C) 2013 Flora M. Díaz-Pérez et al. This is an open access article distributed under the Creative Commons Attribution License, which permits unrestricted use, distribution, and reproduction in any medium, provided the original work is properly cited.

\begin{abstract}
The service quality is a dynamic and multidimensional construct; its study shall include the performance of all actors involved. Therefore, it has been measured the relationship between the variables of quality, satisfaction and existence of industrial disputes in the tourist accommodations of the state of Mérida, Venezuela. A stratified probability sampling and the use of Servqual scale showed a close positive association between the job satisfaction of customer service employees and the service quality, especially during the high tourism season. It was also evidenced during this season that the highest levels of service quality were in those establishments whose employees presented high levels of satisfaction and moderate absence of conflicts.
\end{abstract}

Keywords: Tourism; Quality; Industrial Disputes; Services and Job Satisfaction

\section{Introduction}

The fact that the services are produced and consumed simultaneously and are even sold prior to its production, gives the services a character of inseparability [1], which usually requires a high participation of the customer when interacting with the service provider and with others customers. The inseparability entails challenges in crucial moments, or in face-to-face encounters, hence the customer service personnel are in contact with the customer, with the responsibility of handling the situation, qualifying feelings and emotions [2].

Human Resources (HR) can consolidate the competitiveness within an ethical, social responsibility framework; in which case, the personnel must be carefully selected and trained, and sufficient authority needs to be delegated onto them for a better provision of the service ([3-6]); in other words, it deserves an HR efficient management. According to [7] attention must be addressed to satisfy the employees' needs so as to satisfy the necessities of their customers, since dissatisfied employees will immediately reflect a bad treatment to the customer.

A study is hereby presented, which is circumscribed in the tourist accommodation services and related to the variables aforementioned, so as to underpin the quality of the tourist services in the State of Mérida.

\section{Objectives and Hypotheses}

The objectives of the study are as follow: 1) Know the relationship between the satisfaction, the industrial disputes of customer services employees and the service quality perceived by users of the tourist accommodations in the State of Mérida during high and low seasons; 2) Determine the attitude of customer services employees, and the level of service quality levels in establishments whose employees show different degrees of satisfaction and industrial dispute, during seasons of high influx of users.

To reach the objectives have been formulated the following hypothesis:

Hypothesis 1: Service quality levels perceived by users depend on job satisfaction and conflicts levels experienced by customer service employees of the tourist accommodation in the State of Mérida, during both tourism seasons.

Hypothesis 2: The attitude of customer service employees in view of the high influx of users is favorable.

Hypothesis 3: In tourist accommodation establishments whose customer service employees express high 
levels of satisfaction and low levels of conflict, users show high levels of service quality during periods of high influx.

\section{Literature Review}

In services, including tourism, quality is not limited to a way of doing, or to certain rules, but to a whole process based on the participation of all actors, where HR stands out. As said by [8], employees, especially those in the forefront, must know and be identified with the organization that they work for (products and additional benefits), be able to answer to questions raised by customers or at least find the answers quickly, add quality attributes to the service (security, responsibility and empathy), if an employee does not show enthusiasm for the company or for the products they sell, it will be difficult to delight the customers. When an employee does not know or is not excited about the service, the customer gets the impression that the company is not concerned about him. Employees must feel encouraged and proud of working in the organization and contributing to its success, only then can they transmit enthusiasm based on their own experience, and promote the services and other benefits spontaneously.

Specifically, HR contributes to the service quality by its effectiveness in the intervention, by improving the attention to complaints, by the greater capacity of empathy or the ability to put themselves into the customers' place, by facilitating the interaction, cordiality and kindness with users; moreover, the warranty through the use of technique, technology, interpersonal relationship with internal customers, physical environment, waiting times, among others, depend on HR. Recent studies show that, for users, the quality is represented by a great component of the characteristics in the process of personal attention, being the personal treatment offered the main factor of the process $([9,10])$. Thus, those people who get a high level of satisfaction in their activities, establish very positive and beneficial attitudes, even when there is high demand, i.e. if the staff feels comfortable with its working day and work experience, in an internal atmosphere of quality, an environment is created that leads to satisfying external customers by offering a quality service that directly affects the user's perception. On the contrary, according to [6], when an employee is dissatisfied with his work, he is not involved in his tasks, evades his commitment with the organization, and therefore with his customers, so generally, this unleashes disastrous conesquences, especially when there is a high influx of customers.

Along these lines, the service quality perceived by the user requires the commitment of the staff, in such a way that there exists a direct relationship between the employees and the treatment to customers, therefore spe- cialists such as [11] believe that the employee's satisfaction has an impact on the client's; this variable together with work motivation is what presents a higher correlation with customer's satisfaction, where the higher job satisfaction, the greater quality service. So, according to [9] a company that satisfies the demands of their employees is in an ideal situation to satisfy the users.

In turn, HR also benefit when the organization offers quality services. According to $[8,12]$, quality services not only lead to reducing costs, higher profits and market share, thanks to preserving customers, but also lead to keeping the best HR, based on their satisfaction; given that the latter, first, perceive greater stability in their jobs and economic benefits due to the profitability reached in the company, and secondly, they perceive a pleasant working environment with well-managed operations and feedback, without excessive tensions caused by complaints and claims. In these circumstances, the employee's morale generally rises, they feel attracted and proud for the good reputation and image of the establishment for which they work for. In addition, the internal quality is raised by the favorable attitude that employees have toward others and the way in which the service is provided to each other within the organization (internal customers). According to $[8,13]$, efforts are reduced when recruiting and the training plans will be more successful. Moreover, the employee's retention promotes friendly and loyal relationships with customers; all together makes service quality increase like in a virtuous circle. So it is possible to conclude that service quality contributes to gaining and retaining customers and HR who are motivated and identified with the organization.

In the other hand, according to [14], several studies have tried to identify the key dimensions in the work and its influence on job satisfaction as a part of the work enrichment; among these factors, it shall be pointed out the variety of skills, the identity and the significance of the task, the autonomy, the responsibility and the job's feedback. Each and all of these dimensions can foster job satisfaction and reduce conflict; e.g., the greater the variety of activities of an employee is, the less boring will be. With significant skills, the employee will experience an interesting and important meritorious job; the autonomy represents challenges with the opportunity to satisfy fulfillment needs. However, this autonomy shall be accompanied by a high qualification, which, in turn, has a great motivational component, resulting in an increase of the performance and of the satisfaction. Hence, according to [15], high-qualified workers are generally satisfied and more productive than those with a low qualification.

\section{Methodology}

Regarding data collection, three populations under study 
were defined: tourist accommodations (346 establishments), customer services employees (1423 employees) and users (the average population for the low season is finite: 52,083 users, there is no record of population during the high season). A sample through stratified probability sampling was selected from each group above, which according to the criterion of the maximum variance and with a standard error less than or equal to $5 \%$, were 186 establishments, 312 employees, 400 and 397 users during high and low tourism seasons respectively.

The quality of services was conceived as the difference between the expectations of the user before receiving the service and the perceptions of the same once the service was enjoyed, so it was measured by using the Servqual scale. This scale is one of the most widely spread in services marketing, used by means of a survey to the service users, covering the five determinants dimensions of the quality (tangibility, reliability, empathy, assurance and responsibility). Servqual measures in 22 items the expectations on an excellent service and then, the perceptions about the service received. The scores used to measure each dimension are covered by a scale, which goes from the absolutely essential or totally agree to what is absolutely not essential or totally disagree. Once the data were collected, the differences between expectations and perceptions were called Servqual ${ }^{1}$ total scores; by which when lower are the perceptions with respect to the expectations, lower will be the assessment on the service quality and vice versa [16].

The employee's satisfaction, the degree of conflict and the employee's performance during the high influx of users were measured by using scales such as Likert in surveys performed to 312 customer service employees selected in the sample of the 186 tourist accommodation establishments. Said scales included variables such as satisfaction with their remuneration, benefits and promotion opportunities, satisfaction with team work, with cooperating and helping other people, with the autonomy granted, with the training, the time they have to give careful attention to the users, the personal appearance, the kindness and courtesy before the user, and the energy to carry out their duties. Each scale was subjected to tests of reliability based on the Cronbach's alpha coefficient, all of them resulting in a high reliability (Table 1).

\footnotetext{
${ }^{1}$ The Servqual score was calculated (perceptions-expectations) for each user and for each 22 statements established in the Servqual scale. Then, the totality of statements associated with each criterion was added up and was divided by the amount of statements of the criterion; this way it was obtained the Servqual score that each client grants each criterion. To obtain the Servqual total score of each customer the sum obtained in the Servqual scores of the dimensions of the scale was divided by five. In order to find the total score of the sample of the users interviewed, it was added the individual total score obtained in the previous step and then divided by the number of users interviewed [16].
}

\section{Results}

\subsection{Relationship between the Satisfaction, the Existence of Industrial Disputes and the Service Quality}

In order to test the first hypotheses of this study and to determine the relationship between the variables job satisfaction and service quality levels, as well as the relation between the variables industrial dispute and service quality levels, measured as ordinal categorical variables, a test of significance was used taking Somers' d, Kendall's Tau-b, Kendall's Tau-c, and Gamma as measures of association, which allow using the ordinal status of the variables in study to give a meaning or direction to the connection. From these tests, during both tourism seasons (Tables 2 and 3), it can be inferred with a 95\% of reliability that variables job satisfaction and service quality are related, dependent, during both tourism seasons; i.e., as indicated by the critical values of all calculated coefficients (minor to 0.05), the hypothesis of the test stating the independence between variables is rejected. When observing the positive value of each measure, it is concluded the existence of a positive relationship between variables, where the higher job satisfaction level in the tourist accommodation, the higher levels of service quality users perceive. The same tests were executed to measure the relationship between industrial dispute and service quality levels, with similar results (Tables 4 and 5); that is, a positive relationship where the higher absence of conflict, the greater service quality is reported by the users.

It should be highlighted that the value of the coefficients of association found (Somers' d, Kendall's Tau-b, Kendall's Tau-c, and Gamma) during the high season is superior to the one in the low season, indicating a closer positive relationship between the two variables during the high tourism season.

\subsection{Attitude of Customer Service Employees during the High Season}

In order to corroborate the second hypothesis of this study, a hypothesis test of unilateral contrast was used for the average behavior of the employee during high influx of users (Table 6). In accordance with the small probability indicated by the critical level (minor to 0.05), it is concluded that the average sample of employee's behavior (12.89 points) is far from or different to the average fixed for the test (15 points). The null hypothesis is rejected and it is accepted that the average score is different to 15 points. When observing the reliability interval for the difference in averages, it is also inferred that the average value is less than 15 points, so the behavior is placed in the range of indifferent and not moderately appropriate. 
Table 1. Values of Cronbach's alpha coefficient.

\begin{tabular}{|c|c|c|}
\hline Scales & Cronbach's alpha & Standardized alpha \\
\hline Reliability of the scale of customer service employees' satisfaction & 0.886 & 0.887 \\
\hline Reliability of the scale of employees' attitude during the high influx of users & 0.880 & 0.886 \\
\hline Reliability of the scale of conflicts of customer service employees & 0.909 & 0.911 \\
\hline Reliability of the scale used to measure the expectations of service user-Servqual scale & 0.855 & 0.839 \\
\hline Reliability of the Scale used to measure perceptions of the service user-Servqual scale & 0.835 & 0.859 \\
\hline
\end{tabular}

Note: Prepared from data collected by the researcher.

Table 2. Directional and symmetrical association measures between quality service and job satisfaction levels during the high season.

\begin{tabular}{|c|c|c|c|c|c|c|}
\hline \multicolumn{3}{|c|}{ Directional measures } & \multirow{2}{*}{$\begin{array}{l}\text { Value } \\
0.461\end{array}$} & \multirow{2}{*}{$\begin{array}{c}\text { Asymp. Std. } \\
\text { Error (a) } \\
0.044\end{array}$} & \multirow{2}{*}{$\begin{array}{c}\text { Estimated T (b) } \\
6.870\end{array}$} & \multirow{2}{*}{$\begin{array}{c}\text { Estimated. } \\
\text { Significance }\end{array}$} \\
\hline & & Symmetric & & & & \\
\hline \multirow{2}{*}{$\begin{array}{c}\text { Ordinal by } \\
\text { ordinal }\end{array}$} & Somers' d & Dependent average satisfaction level & 0.319 & 0.042 & 6.870 & 0.000 \\
\hline & & $\begin{array}{l}\text { Dependent Servqual total score } \\
\text { (high season) (grouped) }\end{array}$ & 0.835 & 0.066 & 6.870 & 0.000 \\
\hline
\end{tabular}

a: Considering the alternative hypothesis; b: Using the asymptotic standard error supported in the null hypothesis. Note: Prepared from the data collected by the researcher.

Table 3. Directional and symmetrical association measures between quality service and job satisfaction levels during the low season.

\begin{tabular}{|c|c|c|c|c|c|c|}
\hline \multicolumn{3}{|c|}{ Directional measures } & Value & Asymp. Std. Error (a) & Estimated T (b) & Estimated significance \\
\hline \multirow{3}{*}{$\begin{array}{l}\text { Ordinal by } \\
\text { ordinal }\end{array}$} & \multirow{3}{*}{ Somers' d } & Symmetric & 0.107 & 0.036 & 2.817 & 0.005 \\
\hline & & $\begin{array}{l}\text { Dependent average } \\
\text { satisfaction level }\end{array}$ & 0.073 & 0.026 & 2.817 & 0.005 \\
\hline & & $\begin{array}{c}\text { Dependent Servqual total } \\
\text { score (low season) (grouped) }\end{array}$ & 0.205 & 0.069 & 2.817 & 0.005 \\
\hline
\end{tabular}

a: Considering the alternative hypothesis; b: Using the asymptotic standard error supported in the null hypothesis. Note: Prepared from the data collected by the researcher.

Table 4. Directional and symmetrical association measures between quality service and industrial dispute levels during the high season.

\begin{tabular}{cccccc}
\hline & Directional measures & Value & Asymp. Std. Error (a) & Estimated T (b) & Estimated significance \\
\hline $\begin{array}{c}\text { Ordinal by } \\
\text { ordinal }\end{array}$ & Somers' d & 0.398 & 0.049 & 5.947 & 0.000 \\
$\begin{array}{c}\text { Dependent conflict level } \\
\text { experienced by the customer } \\
\text { services employees } \\
\text { Dependent Servqual total score } \\
\text { (high season) (grouped) }\end{array}$ & 0.273 & 0.042 & 5.947 & 0.000 \\
\hline
\end{tabular}

a: Considering the alternative hypothesis; b: Using the asymptotic standard error supported in the null hypothesis. Note: Prepared from data collected by the researcher.

Table 5. Directional and symmetrical association measures between quality service and industrial dispute levels during the low season.

\begin{tabular}{|c|c|c|c|c|c|c|}
\hline \multicolumn{3}{|c|}{ Directional Measures } & \multirow{2}{*}{$\begin{array}{l}\text { Value } \\
0.122\end{array}$} & \multirow{2}{*}{$\begin{array}{c}\text { Asymp. Std. Error (a) } \\
0.036\end{array}$} & \multirow{2}{*}{$\begin{array}{c}\text { Estimated } \mathrm{T}(\mathrm{b}) \\
3.210\end{array}$} & \multirow{2}{*}{$\begin{array}{c}\text { Estimated significance } \\
0.001\end{array}$} \\
\hline & & Symmetric & & & & \\
\hline \multirow[t]{2}{*}{$\begin{array}{l}\text { Ordinal by } \\
\text { ordinal }\end{array}$} & Somers' d & $\begin{array}{l}\text { Dependent conflict level } \\
\text { experienced by the customer } \\
\text { services employees }\end{array}$ & 0.082 & 0.026 & 3.210 & 0.001 \\
\hline & & $\begin{array}{l}\text { Dependent Servqual total score } \\
\text { (low season) (grouped) }\end{array}$ & 0.238 & 0.068 & 3.210 & 0.001 \\
\hline
\end{tabular}

a: Considering the alternative hypothesis; b: Using the asymptotic standard error supported in the null hypothesis. Note: Prepared from data collected by the researcher. 
Table 6. Test of unilateral contrast hypothesis for the average behavior of the employee during high influx of users.

\begin{tabular}{|c|c|c|c|c|c|c|c|}
\hline \multicolumn{2}{|c|}{$\begin{array}{l}\text { Scale of employee's behavior during high } \\
\text { influx of users }\end{array}$} & Totally agree & \multicolumn{2}{|c|}{ Moderately agree } & Indifferent & $\begin{array}{l}\text { Moderately } \\
\text { disagree }\end{array}$ & $\begin{array}{l}\text { Totally } \\
\text { disagree }\end{array}$ \\
\hline \multicolumn{2}{|c|}{$\begin{array}{l}\text { Feels he has enough time to offer a careful and } \\
\text { individualized attention in view of large influx of } \\
\text { customers }\end{array}$} & 5 & \multicolumn{2}{|l|}{4} & 3 & 2 & 1 \\
\hline \multicolumn{2}{|c|}{$\begin{array}{l}\text { Has impeccable personal appearance and clothing in view } \\
\text { of large influx of customers }\end{array}$} & 5 & \multicolumn{2}{|l|}{4} & 3 & 2 & 1 \\
\hline \multicolumn{2}{|c|}{$\begin{array}{l}\text { Polite and kind behavior in view of large influx of } \\
\text { customers }\end{array}$} & 5 & \multicolumn{2}{|l|}{4} & 3 & 2 & 1 \\
\hline \multicolumn{2}{|c|}{ Feels in a good mood in view of large influx of customers } & 5 & \multicolumn{2}{|l|}{4} & 3 & 2 & 1 \\
\hline \multicolumn{2}{|c|}{ Feels energetic in view of large influx of customers } & 5 & \multicolumn{2}{|l|}{4} & 3 & 2 & 1 \\
\hline \multirow{2}{*}{\multicolumn{2}{|c|}{ Total }} & 25 & \multicolumn{2}{|l|}{20} & 15 & 10 & 5 \\
\hline & & $\begin{array}{l}25-20 \\
\text { Totally } \\
\text { appropriate }\end{array}$ & \multicolumn{2}{|c|}{$\begin{array}{c}20 \text { - } 15 \\
\text { Moderately } \\
\text { appropriate }\end{array}$} & $\begin{array}{c}15-10 \\
\text { Indifferent }\end{array}$ & $\begin{array}{c}10 \text { - } 5 \\
\text { Moderately } \\
\text { inappropriate }\end{array}$ & $\begin{array}{c}5-0 \\
\text { Totally } \\
\text { inappropriate }\end{array}$ \\
\hline \multicolumn{2}{|l|}{ Statistician for a sample } & $\mathrm{N}$ & Average & \multicolumn{2}{|c|}{ Standard deviation } & \multicolumn{2}{|c|}{ SE of the mean } \\
\hline \multirow{2}{*}{\multicolumn{2}{|c|}{$\begin{array}{l}\text { Employee's performance level in view of high influx } \\
\text { of users }\end{array}$}} & 312 & 12.8910 & \multicolumn{2}{|c|}{4.28573} & \multicolumn{2}{|c|}{0.24263} \\
\hline & & & \multicolumn{3}{|c|}{ Test value $=15$} & & \\
\hline \multirow[t]{2}{*}{ Test for a sample } & $\mathrm{t}$ & Gl & $\begin{array}{c}\text { Sig. } \\
\text { (Bilateral) }\end{array}$ & & $\begin{array}{l}\text { ifference in } \\
\text { averages }\end{array}$ & \multicolumn{2}{|c|}{$\begin{array}{l}95 \% \text { reliability interval for the } \\
\text { difference }\end{array}$} \\
\hline & Lower & Superior & Lower & & Superior & Lower & Superior \\
\hline $\begin{array}{l}\text { Employee's performance level in view of } \\
\text { high influx of users }\end{array}$ & -8.692 & 311 & 0.000 & & -2.10897 & -2.5864 & -1.6316 \\
\hline
\end{tabular}

Note: Prepared from the data collected by the researcher.

\subsection{Behavior of the Service Quality before Conflict and Job Satisfaction}

In order to determine the behavior of service quality expressed by the users, in the establishments grouped according to the degree of satisfaction and the degree of conflict of the employees during the high influx of users, a factorial ANOVA was carried out in the high tourist season. Considering the above, the third hypothesis of the research was tested. The results in Table 7 reflect the individual effect and set of both independent and categorical variables (satisfaction and conflict levels) on the dependent quantitative variable (of interval) (Servqual Total Score: service quality). The critical level of statistical F $(p=0.000<0.05)$ indicates that the model explains a significant part of the variation in the dependent variable (service quality), specifically a $56.6 \%$. The individual effect of the satisfaction variable is significant (significance $=0.009<0.05$ ), indicating that the groups of establishments defined by different degrees of satisfaction have an average of service quality significantly different. Likewise, the individual effect of the conflict variable is displayed significant (significance $=0.005<$ 0.05 ) indicating that the average of service quality of the groups defined by different degrees of conflict differs.
The interaction effect between the independents variables is not significant, i.e., there is no interaction effect between the independent variables studied.

With the purpose of knowing which group of establishments defined by degree of satisfaction and industrial dispute of its employees obtains the highest service quality levels, a comparison with hindsight or post hoc was carried out for each independent variable (Table 8). According to the Games-Hoewel method, those establishments whose employees seem completely satisfied present higher average quality levels compared to those groups whose employees seem totally and moderately dissatisfied, with indifferent attitude; in turn, those establishments whose employees seem totally dissatisfied show lower quality levels compared to the groups whose employees seem moderately dissatisfied and totally satisfied. In Table 9, there are groups of establishments whose average of service quality do not differ, grouped into subsets; that is, there are only two groups whose Servqual total scores are homogeneous. The subset 1 group the negative Servqual scores (quality deficit) corresponding to the establishments whose employees were totally and moderately dissatisfied and indifferent; and the second subgroup only presents the establishments whose employees are completely satisfied and whose 
Table 7. Test of the inter-subjects effects of factorial ANOVA. Dependent variable: Servqual total score.

\begin{tabular}{|c|c|c|c|c|c|}
\hline Source & Sum of squares type III & Gl & Root mean square & $\mathrm{F}$ & Significance \\
\hline Corrected model & 14.112 (a) & 5 & 2.822 & 79.908 & 0.000 \\
\hline Intersection & 2.734 & 1 & 2.734 & 77.420 & 0.000 \\
\hline Satisfaction & 0.342 & 2 & 0.171 & 4.839 & 0.009 \\
\hline Conflict & 0.313 & 1 & 0.113 & 3.354 & 0.005 \\
\hline Satisfaction * Conflict & 0.013 & 1 & 0.013 & 0.354 & 0.552 \\
\hline Error & 10.808 & 306 & 0.035 & & \\
\hline Total & 68.570 & 312 & & & \\
\hline Corrected Total & 24.920 & 311 & & & \\
\hline
\end{tabular}

a: $\mathrm{R}$ square $=0.566(\mathrm{R}$ square corrected $=0.559)$. Note: Prepared from the data collected by the researcher.

Table 8. Post hoc comparison. Multiple comparisons.

\begin{tabular}{|c|c|c|c|c|c|c|c|}
\hline \multirow{2}{*}{\multicolumn{2}{|c|}{ (I) Average satisfaction level }} & \multirow{2}{*}{$\begin{array}{c}\text { (J) Average satisfaction } \\
\text { level }\end{array}$} & \multirow{2}{*}{$\begin{array}{c}\begin{array}{c}\text { Difference } \\
\text { between } \\
\text { averages }(\mathrm{I}-\mathrm{J})\end{array} \\
\text { Inferior limit }\end{array}$} & \multirow{2}{*}{$\begin{array}{c}\text { Standard } \\
\text { Error } \\
\begin{array}{c}\text { Superior } \\
\text { limit }\end{array}\end{array}$} & \multirow{2}{*}{$\begin{array}{l}\text { Signification } \\
\text { Inferior limit }\end{array}$} & \multicolumn{2}{|c|}{ Reliability interval 95\% } \\
\hline & & & & & & $\begin{array}{l}\text { Superior } \\
\text { limit }\end{array}$ & Inferior limit \\
\hline \multirow{10}{*}{$\begin{array}{l}\text { Games-H } \\
\text { owell }\end{array}$} & \multirow{2}{*}{ Totally dissatisfied } & Moderately dissatisfied & $-0.1615\left(^{*}\right)$ & 0.01229 & 0.000 & -0.1933 & -0.1298 \\
\hline & & Completely satisfied & $-0.8453\left(^{*}\right)$ & 0.00880 & 0.000 & -0.8692 & -0.8214 \\
\hline & \multirow{3}{*}{$\begin{array}{l}\text { Moderately } \\
\text { dissatisfied }\end{array}$} & Completely dissatisfied & $0.1615\left(^{*}\right)$ & 0.01229 & 0.000 & 0.1298 & 0.1933 \\
\hline & & Indifferent & $0.1615\left(^{*}\right)$ & 0.01229 & 0.000 & 0.1298 & 0.1933 \\
\hline & & Completely satisfied & $-0.6838\left(^{*}\right)$ & 0.01511 & 0.000 & -0.7230 & -0.6446 \\
\hline & \multirow[t]{2}{*}{ Indifferent } & Moderately dissatisfied & $-0.1615\left(^{*}\right)$ & 0.01229 & 0.000 & -0.1933 & -0.1298 \\
\hline & & Completely satisfied & $-0.8453(*)$ & 0.00880 & 0.000 & -0.8692 & -0.8214 \\
\hline & \multirow{3}{*}{$\begin{array}{l}\text { Completely } \\
\text { satisfied }\end{array}$} & Completely dissatisfied & $0.8453\left(^{*}\right)$ & 0.00880 & 0.000 & 0.8214 & 0.8692 \\
\hline & & Moderately dissatisfied & $0.6838\left(^{*}\right)$ & 0.01511 & 0.000 & 0.6446 & 0.7230 \\
\hline & & Indifferent & $0.8453\left(^{*}\right)$ & 0.00880 & 0.000 & 0.8214 & 0.8692 \\
\hline \multirow{2}{*}{\multicolumn{2}{|c|}{$\begin{array}{l}\text { (I) Conflict level experienced by } \\
\text { service customer employees }\end{array}$}} & \multirow{2}{*}{$\begin{array}{l}\text { (J) Conflict level } \\
\text { experienced by service } \\
\text { customer employees }\end{array}$} & $\begin{array}{c}\text { Difference } \\
\text { between } \\
\text { averages }(\mathrm{I}-\mathrm{J})\end{array}$ & $\begin{array}{l}\text { Standard } \\
\text { error }\end{array}$ & Signification & \multicolumn{2}{|c|}{ Reliability interval 95\%. } \\
\hline & & & Inferior limit & $\begin{array}{l}\text { Superior } \\
\text { limit }\end{array}$ & Inferior limit & Superior limit & $\begin{array}{l}\text { Inferior } \\
\text { limit }\end{array}$ \\
\hline \multirow{5}{*}{$\begin{array}{l}\text { Games-H } \\
\text { owell }\end{array}$} & Total conflict level & Moderate without conflict & $-0.6053\left(^{*}\right)$ & 0.07234 & 0.000 & -0.8062 & -0.4044 \\
\hline & \multirow{2}{*}{$\begin{array}{l}\text { Moderate conflict } \\
\text { level }\end{array}$} & Total conflict level & -0.0880 & 0.07281 & 0.477 & -0.2892 & 0.1133 \\
\hline & & Moderate without conflict & $-0.6933\left(^{*}\right)$ & 0,01496 & 0.000 & -0.7286 & -0.6579 \\
\hline & \multirow{2}{*}{$\begin{array}{l}\text { Moderate without } \\
\text { conflict }\end{array}$} & Total conflict level & $0.6053\left(^{*}\right)$ & 0.07234 & 0.000 & 0.4044 & 0.8062 \\
\hline & & Moderate conflict level & $0.6933\left(^{*}\right)$ & 0.01496 & 0.000 & 0.6579 & 0.7286 \\
\hline
\end{tabular}

Based on the observed averages. ${ }^{*}$ The average difference is significant at level 0.05 . Note: Prepared from the data collected by the researcher. 
Table 9. Homogenous subgroups. Servqual total score.

\begin{tabular}{lcccc}
\hline & & $\mathrm{N}$ & \multicolumn{2}{c}{ Subset } \\
\cline { 2 - 4 } Average satisfaction level & 1 & 2 & 1 \\
\hline Completely dissatisfied & 8 & -0.6000 & -0.6000 \\
Tukey B (a,b,c) & Indifferent & 3 & -0.4385 & 0.2453
\end{tabular}

The error term is the Root mean square $($ Error $)=0.035$. a: Uses the sample size of the harmonic mean $=8.109 ; \mathrm{c}$ : Alpha $=0.05$.

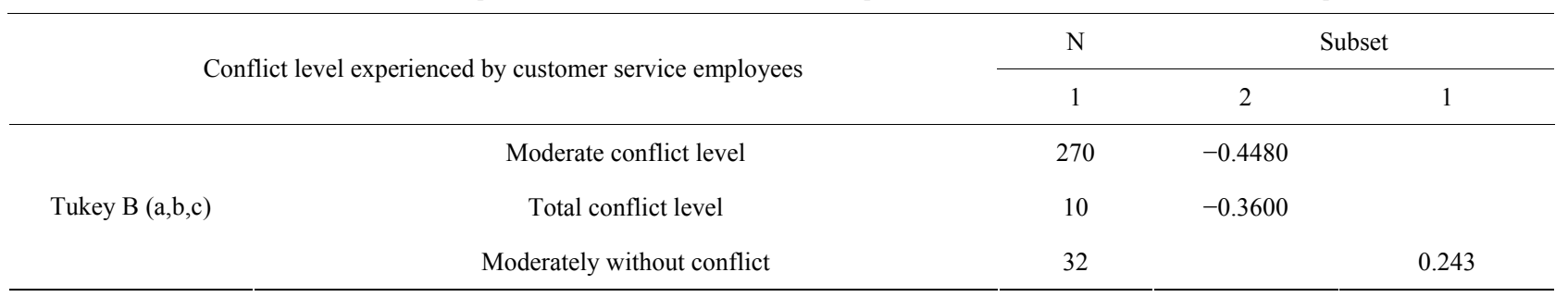

It shows the averages for the groups in homogeneous subsets. Based on the sum of squares type III. The error term is the Root mean square (Error) $=0.035$. a: Uses the sample size of the harmonic mean $=22.230$; b: The sizes of the groups are different. The harmonic mean of the sizes of the groups will be used. It is not guaranteed the error levels type I; $\mathrm{c}$ : Alpha $=0.05$. Note: Prepared from data collected by the researcher.

average Servqual total score is positive on average (0.2453) (excellent quality).

With respect to the independent variable: conflict level, there is a similar behavior. According to the post hoc comparison in Table $\mathbf{8}$, and the critical value of the test ( significance $=0.00$ ), it is inferred that there are significant differences in the service quality of establishments groups defined by a moderate level without conflicts and the rest of conflict levels (total and moderate conflict), resulting the former in superior averages of quality. Table 9 presents the average levels of homogeneous service quality for the establishments grouped according to the conflict level expressed by their employees. The establishments whose employees expressed moderate and total conflict level with negative average levels of service quality are located in subgroup 2, while in group 1, we can see those establishments whose employees expressed moderate absence of conflicts with positive average levels of service quality.

The behavior of the dependent variable (service quality) versus the satisfaction and industrial disputes levels is shown on the profile graph built as a part of the factorial ANOVA carried out. In Figure 1, the same results observed in Tables 8 and $\mathbf{9}$ are shown, the establishments whose employees show indifference and moderate dissatisfaction levels, total and moderate conflict levels, present lower average Servqual scores (negative) than the establishments defined by totally satisfied employees and moderately without conflicts, whose average Servqual scores are higher (positive). It is also observed the absence of interaction effect between the independent variables, with a homogeneous or repeated behavior of the average values of service quality, in the groups defined by conflict level and the groups defined according to their satisfaction level, where the greater satisfaction and absence of conflict, the highest Servqual score.

Under the results presented by the ANOVA factorial performed, hypothesis 3 is accepted.

\section{Findings and Recommendations}

In the tourist accommodation of the State of Mérida, a positive association was found between the variables of service quality and job satisfaction, and between the variable quality service and industrial disputes experienced by customer service employees; where the highest levels of service quality correspond to higher levels of job satisfaction and absence of conflict among the customer service employees. Said relationships were demonstrated during both tourism seasons, although the slightly closest or highest relations were found during the high tourism season.

It is understood that during the high tourism season is important to take care of customer service employees' satisfaction, and also of their performance, considering the relation found previously and the presence of indifferent or inappropriate behavior of said employees during this season. Furthermore, the highest levels of service quality reported by the users are shown in those establishments whose employees expressed high levels of satisfaction and moderate absence of conflicts; on the contrary, lowest levels of quality were found in the establishments whose customer service employees expressed total or moderate conflict level and moderate and indifferent dissatisfaction levels. 


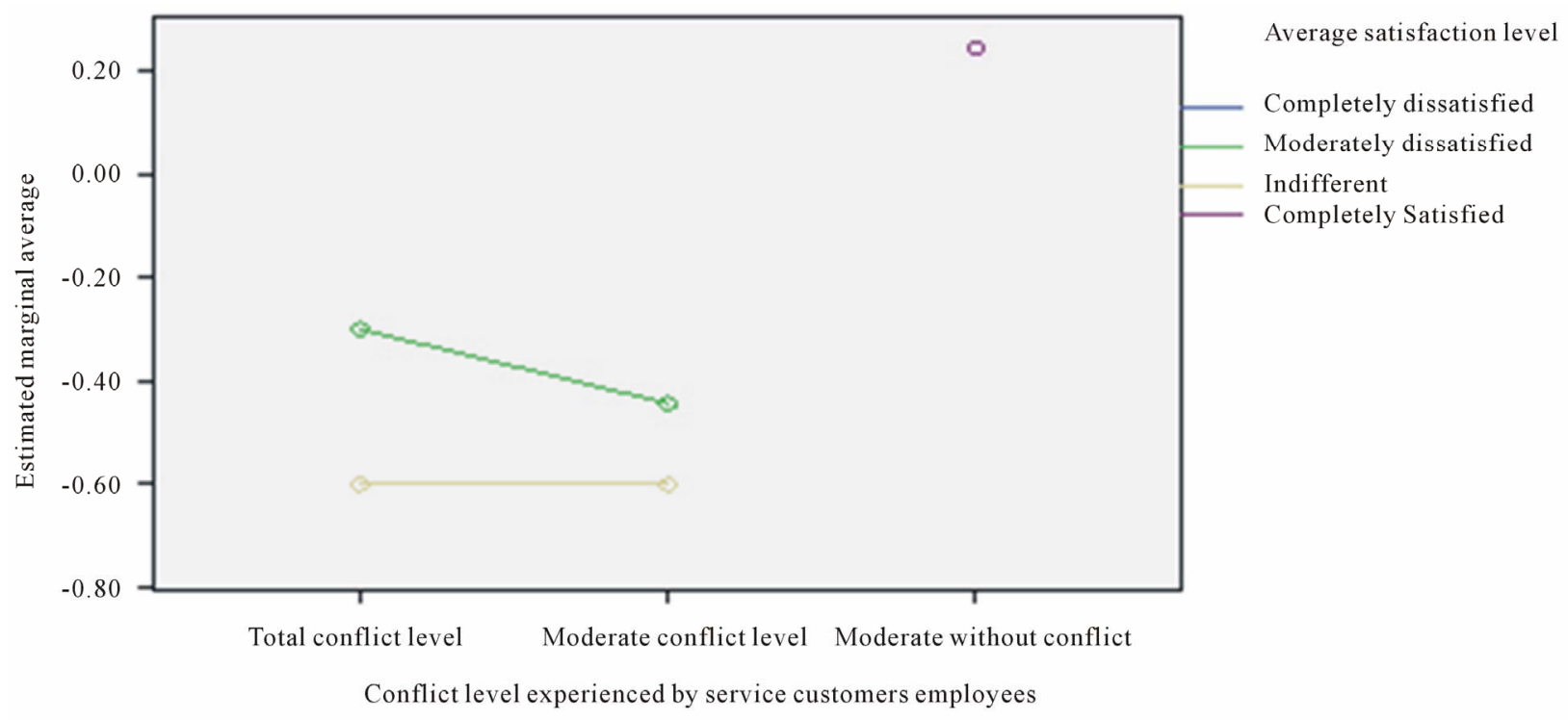

Figure 1. Graph of profile estimated marginal means of Servqual scores by conflict and job satisfaction level. Note: Prepared from data collected by the researcher.

Then, in the tourist accommodation establishments of the State of Mérida, it is necessary to pay attention to job satisfaction and the existence of conflicts, due to the high association with the quality service level perceived by users; thus, the gap of compliance with service standards on the employees' side will be reduced.

In the first place, surveys shall be performed in these establishments periodically in order to measure job satisfaction and presence of conflicts, to find the dissatisfaction causes and, if so, design corrective strategies based on examinations and continuous improvement of the processes in the communication, in the development and in the training of human resources. The nature of this thesis itself is a main determinant of the satisfaction with the job position.

\section{REFERENCES}

[1] I. Begg, "The Service Sector in Regional Development," Regional Studies, Vol. 27, No. , 1993, pp. 17-25.

[2] K. Albrecht and R. Zemke, "Gerencia de Servicio. Cómo Hacer Negocios en una Nueva Economía," 3rd Editores, Bogotá, 1999.

[3] M. G. Solarte, "Los Macro-Procesos: Un nuevo Enfoque en el Estudio de la Gestión Humana," Pensamiento y Gestión, No. 27, 2009, pp. 162-200.

[4] W. E. Deming, "Out of the Crisis: Quality, Productivity, and Competitive Position," Cambridge University Press, Cambridge, 1988.

[5] J. E. Evans and W. M. Lindsay, "Administración y Control de la Calidad," 4th Edition, Thomson Editorial Mexicana, México, 1999.

[6] W. B. Werther and D. Keith, "Human Resources and Personnel Management," 5th Edition, McGraw-Hill, Bos- ton, 1996.

[7] T. J. López-Guzmán, S. Sanchez and M. Nascimento, "La Satisfacción Laboral como Valor Intangible de los Recursos Humanos: Un Estudio de Casos en Establecimientos Hoteleros," Teoría y Praxis, Vol. 7, 2010, pp. 35 53.

[8] L. Berry, "Big Ideas in Services Marketing," Journal of Consumer Marketing, Vol. 3, No. 2, 1986, pp. 47-51.

[9] J. Ponce, H. Reyes and G. Ponce, "Satisfacción Laboral y Calidad de Atención de Enfermería en una Unidad Médica de Alta Especialidad," Revista Enfermería IMSS, Vol. 14, No. 2, 2006, pp. 65-73.

[10] J. M. Peiró, "Stress and Coping at Work: New Research Trends and Their Implications for Practice," In: K. Naswall, Ed., The Individual in the Changing Working Life, Cambridge University Press, Cambridge, 2008, p. 442.

[11] A. B. Dutka, "Demographic Trends in the Labor Force," In: E. Ginzberg, Ed., The Changing U. Labor Market, Boulder, C.O., Westview, 1994, pp. 18-32.

[12] C. H. Lovelock, "Classifying Services to Gain Strategic Marketing Insights," Journal of Marketing, Vol. 47, 1983, pp. 9-20.

[13] V. Zeithaml, A. Parasuraman and L. Berry, "Problems and Strategies in Services Marketing," Journal of Marketing, Vol. 49, 1985, pp. 33-46.

[14] M. Atalaya, "Satisfacción Laboral y Productividad," Revista de Psicología, Vol. 3, No. 5, 1999, pp. 46-76. http://sisbib.unmsm.edu.pe/bvrevistas/psicologia/1999_n5 /index.htm

[15] S. Robbins, "Organizational Behavior. Concepts, Controversies, and Applications," 9th Edition, Prentice Hall, Inc., Upper Saddle River, 1998.

[16] A. Parasuraman, V. Zeithaml and L. Berry, “A Conceptual Model of Service Quality and Its Implications for Future Research," Journal of Marketing, Vol. 49, No. 4, 1985, pp. 41-50. 